Arq. Bras. Med. Vet. Zootec., v.66, n.5, p.1401-1405, 2014

\title{
Fetal malformation in a marmoset (Callithrix jacchus): case report
}

\author{
[Malformação fetal em sagui-de-tufo-branco (Callithrix jacchus): relato de caso] \\ M.C. Ferraz, A.V.R. Matos, N.C. Prestes, J.C.P. Ferreira, \\ L.C. Francelino, F.S. Cunha, E. Oba \\ Faculdade de Medicina Veterinária e Zootecnia - Universidade Estadual \\ Paulista - FMVZ - Unesp - Botucatu, SP
}

\begin{abstract}
Callithrix jacchus is a neotropical primate adaptable in captivity. Colonies can be easily established in a short time and at low cost compared to other species of larger primates, which are normally used in laboratory. Because they are phylogenetically similar to humans in situations that induce anxiety, these small primates are increasingly being used in research involving the stress response. Wild animals in captivity are subjected to a series of stressful events that depending on the duration and intensity can modify the organic homeostasis. Observed in this study, serious problems occurred with the formation in fetal offspring of Callithrix jacchus kept in an environment with a high degree of stress.
\end{abstract}

Keywords: Callithrix jacchus, stress, cortisol, formation fetal

\section{RESUMO}

O Callithrix jacchus é um primata neotropical de fácil adaptação em cativeiro. As colônias podem ser facilmente estabelecidas em um curto espaço de tempo e a um custo baixo comparado a outras espécies de primatas maiores, que são normalmente utilizados em laboratório. Por serem filogeneticamente semelhantes aos seres humanos em situações que induzem à ansiedade, esses pequenos primatas estão sendo cada vez mais utilizados em pesquisas que envolvam a resposta ao estresse. Animais silvestres em cativeiro estão submetidos a uma série de eventos estressores, os quais, dependendo da sua duração e intensidade, podem modificar a homeostase orgânica. Observaram-se, neste estudo, graves problemas ocorridos com a formação fetal nas proles de Callithrix jacchus mantidos em ambiente com alto grau de estresse.

Palavras-chave: Callithrix jacchus, estresse, cortisol, formação fetal

\section{INTRODUCTION}

The Callithrix jacchus is naturally found in the northeast of Brazil (Stevenson and Rylands, 1988; Modolin and Cerqueira, 1994). These animals live in groups with high degrees of kinship, usually with a single reproducing female (Stevenson and Rylands, 1988).

As they are phylogenetically similar to humans in situations that induce anxiety, these small primates are increasingly being used in researches that involve stress response (Barros and Tomaz, 2002). The average gestation time is
144 days (French, et al., 1996). A large offspring can cause problems to callitrichid females, as the weight of the litter can surpass $10 \%$ of the mother's body weight (Eisenberg, 1977).

The Callithrix jacchus is easily adaptable to captivity, handling and experimental procedures, and it is even easier if a reward system is implemented. Captivity colonies can be easily established in a short time and at lower costs when compared to larger primates, which are normally used in laboratories (Hearn, 1983).

Recebido em 4 de fevereiro de 2014

Aceito em 14 de abril de 2014

E-mail: dra_myrnacampos@yahoo.com.br 
However, it is known that animals held in captivity habitually undergo stressful situations, and during the pregnancy, the body of the mother goes through many physical and chemical changes, including altered production rates of certain hormones. Higher cortisol levels are usually seen in pregnant women $(\mathrm{Ng}, 2011)$. Such elevation is essential for the growth of the embryo. However, an excessive rise in cortisol levels can permanently modify the fetal growth (Seckl and Holmes, 2007).

The aim of this study was to report the occurrence of fetal malformations in Callithrix jacchus marmosets.

\section{CASE REPORT}

The reports presented happened to seven female marmosets (Callithrix jacchus) housed in a colony of the Wild Animal Medicine and Research Center of the School of Veterinary Medicine and Husbandry "Júlio Mesquita Filho" - FMVZ - UNESP), in Botucatu - São Paulo, Brazil, 22 $53^{\circ} 09^{\prime}$ 'S, $48^{\circ} 26^{\circ} 42^{\prime \prime} \mathrm{W}$, with an annual mean temperature of $22^{\circ} \mathrm{C}$.

The animals were part of a non-invasive monitoring experiment of the reproductive function of Callithrix jacchus, males and females. The experiment did not aim to cause damage to the health of the animals. However, the stressful conditions of captivity, such as the presence of predators next to the enclosures, intense cold and sounds may have caused the problems seen in during the research period. The experiment took place between July 2010 and December 2011, under the ethics committee protocol \#126/2010.

To avoid consanguineous breeding, the animals were collected from two different sites, the Tietê Ecologic Park, and the Municipal Zoo of Sorocaba - Sorocaba-SP- Brazil).

The females gestated from July to December, 2011. Three of the them were taken to the animal reproduction clinic with the following history:

Female 1: the contractions started at 10:30 a.m., $11 / 26 / 2011$. Manual removal of an insinuating fetus was performed, waiting until 11/27/2011, with the expectation that the other fetus would naturally be expelled. As natural birth did not occur, the female underwent cesarean section surgery.

Female 2: contractions started at 07:00 a.m., $12 / 13 / 2011$. However, birthing is usually quick in this species, and after three hours waiting with for the expulsion of the litter, fetal death was pronounced. Cesarean section surgery was performed at 11:00 a.m. of the same day.

Female 3: uterine atony. Cesarean section surgery was performed in $12 / 21 / 2011$, in the morning. The female was eating normally on the previous day, but presented apathy and anorexia on the $21^{\text {st }}$ day.

After radiography (Figure 1), physical and ultrasonography examination, where fetal death and relatively large fetal size compared to the size of the mother was found, the animals were prepared for surgery under a compatible anesthetic protocol (Figure 2 and 3).

The anesthetic induction was performed after pre-oxygenation, using an induction chamber with diluted isoflurane (4\% vol.) and $\mathrm{O}_{2} 100 \%$. After reaching an adequate muscle relaxation and decubitus, the animals were removed from the box and the induction was complemented using isoflurane through facial mask. The orotracheal intubation was performed using a $14 \mathrm{G}$ catheter, after palpebral, interdigital and laringotracheal reflexes were confirmed to be absent. A topical administration of $2 \%$ lidocaine was used to facilitate intubation. A complete anesthetic circuit, appropriate for the reduced size of the animals, was crafted, so that no $\mathrm{CO}_{2}$ would be rebreathed, as well as to maintain the airway clear during the anesthetic procedure, allowing proper ventilation. The anesthetic maintenance was achieved using diluted isoflurane (0.5-2.5 vol. \%) and $\mathrm{O}_{2} 100 \%$, and intraoperative analgesia was performed using morphine or methadone $(0.1 \mathrm{mg} / \mathrm{kg})$, IM. Fluid administration was performed using ringer-lactate solution, administered using an infusion pump at $5 \mathrm{~mL} / \mathrm{kg} / \mathrm{h}$. The animals were monitored using ECG, Doppler and capnography. The temperature of the animals was sustained using a hot air inflator during the entire procedure. At the end of the procedure, the anesthetic administration was discontinued and the orotracheal catheter was removed after the protective reflexes returned, leading to a steady 
recovery, with no complications. Meloxicam was administered to the animals $(0.1 \mathrm{mg} / \mathrm{kg} \mathrm{IM})$ as a post-operatory analgesic (Prestes et al., 2014).

The surgery was performed using the classic standard technique. The uterine, abdominal wall and skin sutures were performed using threads with a diameter compatible with the size of the animals.

\section{DISCUSSION}

Of the seven pregnant females, three underwent cesarian section surgery and four had natural births, being that only two of the babies from one couple survived the natural birth. The weight of the females and biometry of their respective offspring are described in Table 1. The weight of the female Callithrix jacchus and biometry of the stillborn from the natural births are described in Table 2.

The ten stillborn presented cranial malformation, especially cleft palate (Figures 4 e 5). Stress alters the level of many hormones and other molecules found in the blood, which can cause modifications in the fetus.
Prenatal stress affects the placenta in particular, lowering the function of this organ by reducing the level of nutrients and oxygen that reach the fetus. The mechanism of this effect results in high levels of adrenalin in the blood, which induce an increase in vascular resistance and a reduction in the blood flow to the placenta (Charil et al., 2010).

In a Callithrix jacchus colony, environmental stress was the main cause of a large number of abortions (Johnson et al., 1991).

Certain morphological alterations, as well as the physiology of the uterus or even yet, maternal hormone distribution can lead to variations in the embryogenesis that culminate in the birth of a child with cleft palate fissure (Modoline Cerqueira, 1994). Such morphological alterations are associated with the topography of the uterus and the condition of the embryo in the uterine cavity. Such circumstances can cause physiological modifications that, in a certain way, lower the blood flow. The subsequent tissue hypoxia aggravates with the fast development of the embryonic structures (Capelozza Filho, 1988).

Table 1. Weight of the female Callithrix jacchus that underwent cesarean section surgery and biometry of their respective offspring

\begin{tabular}{cccccccc} 
Female & $\begin{array}{c}\text { \# of } \\
\text { fetuses }\end{array}$ & $\begin{array}{c}\text { Weight of the } \\
\text { mothers }\end{array}$ & $\begin{array}{c}\text { Weight } \\
\text { of the } \\
\text { fetuses }\end{array}$ & $\begin{array}{c}\text { Sex of } \\
\text { the } \\
\text { fetuses }\end{array}$ & $\begin{array}{c}\text { Fetal } \\
\text { length }\end{array}$ & $\begin{array}{c}\text { Tail length } \\
\text { of the } \\
\text { fetuses }\end{array}$ & $\begin{array}{c}\text { Cranial } \\
\text { diameter of } \\
\text { the fetuses }\end{array}$ \\
\hline 1 & 2 & $264 \mathrm{~g}$ & $34.4 \mathrm{~g}$ & $\mathrm{~F}$ & $15 \mathrm{~cm}$ & $10 \mathrm{~cm}$ & $9 \mathrm{~cm}$ \\
& 2 & $338 \mathrm{~g}$ & $34.0 \mathrm{~g}$ & $\mathrm{~F}$ & $13 \mathrm{~cm}$ & $9 \mathrm{~cm}$ & $9.5 \mathrm{~cm}$ \\
& 2 & & $32.0 \mathrm{~g}$ & M & $11 \mathrm{~cm}$ & $10 \mathrm{~cm}$ & $9 \mathrm{~cm}$ \\
& 2 & $28 \mathrm{~g}$ & F & $11 \mathrm{~cm}$ & $9 \mathrm{~cm}$ & $7 \mathrm{~cm}$ \\
& 2 & $28 \mathrm{~g}$ & F & $11 \mathrm{~cm}$ & $8 \mathrm{~cm}$ & $10 \mathrm{~cm}$ \\
\hline
\end{tabular}

Table 2. Weight of the female Callithrix jacchus and biometry of their respective offspring from natural birth

\begin{tabular}{|c|c|c|c|c|c|c|c|}
\hline Female & $\begin{array}{c}\text { \# of } \\
\text { fetuses }\end{array}$ & $\begin{array}{l}\text { Weight of } \\
\text { the } \\
\text { mothers }\end{array}$ & $\begin{array}{l}\text { Weight } \\
\text { of the } \\
\text { fetuses }\end{array}$ & $\begin{array}{l}\text { Sex of } \\
\text { the } \\
\text { fetuses }\end{array}$ & Fetal length & $\begin{array}{c}\text { Tail length } \\
\text { of the } \\
\text { fetuses }\end{array}$ & $\begin{array}{c}\text { Cranial } \\
\text { diameter of } \\
\text { the fetuses }\end{array}$ \\
\hline \multirow[t]{2}{*}{1} & 2 & $336 \mathrm{~g}$ & $34.0 \mathrm{~g}$ & $\mathrm{M}$ & $14.5 \mathrm{~cm}$ & $12.5 \mathrm{~cm}$ & $9.5 \mathrm{~cm}$ \\
\hline & & & $34.4 \mathrm{~g}$ & M & $14.5 \mathrm{~cm}$ & $10.5 \mathrm{~cm}$ & $10.5 \mathrm{~cm}$ \\
\hline \multirow[t]{2}{*}{2} & 2 & $376 \mathrm{~g}$ & $35.0 \mathrm{~g}$ & $\mathrm{~F}$ & $14 \mathrm{~cm}$ & $10 \mathrm{~cm}$ & $9.5 \mathrm{~cm}$ \\
\hline & & & $34.0 \mathrm{~g}$ & $\mathrm{~F}$ & $14 \mathrm{~cm}$ & $11 \mathrm{~cm}$ & $9 \mathrm{~cm}$ \\
\hline \multirow[t]{2}{*}{3} & 2 & $254 \mathrm{~g}$ & $26 \mathrm{~g}$ & $\mathrm{~F}$ & $12 \mathrm{~cm}$ & $9 \mathrm{~cm}$ & $7 \mathrm{~cm}$ \\
\hline & & & $27 \mathrm{~g}$ & $\mathrm{~F}$ & $11 \mathrm{~cm}$ & $9 \mathrm{~cm}$ & $8 \mathrm{~cm}$ \\
\hline
\end{tabular}




\section{Ferraz et al.}

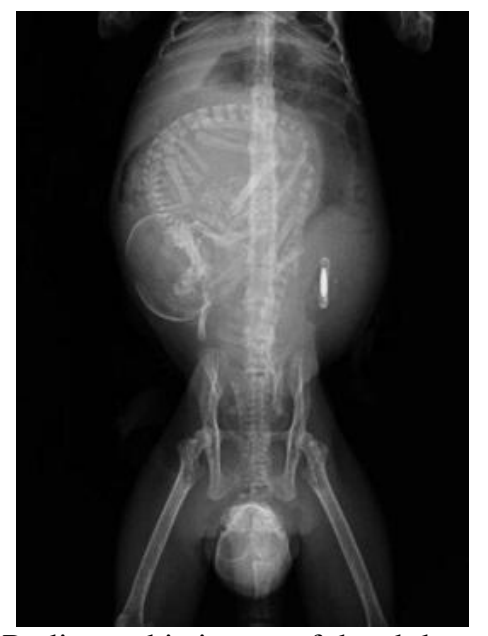

Figure 1. Radiographic image of the abdomen of a female Callithrix jacchus that underwent cesarean section.

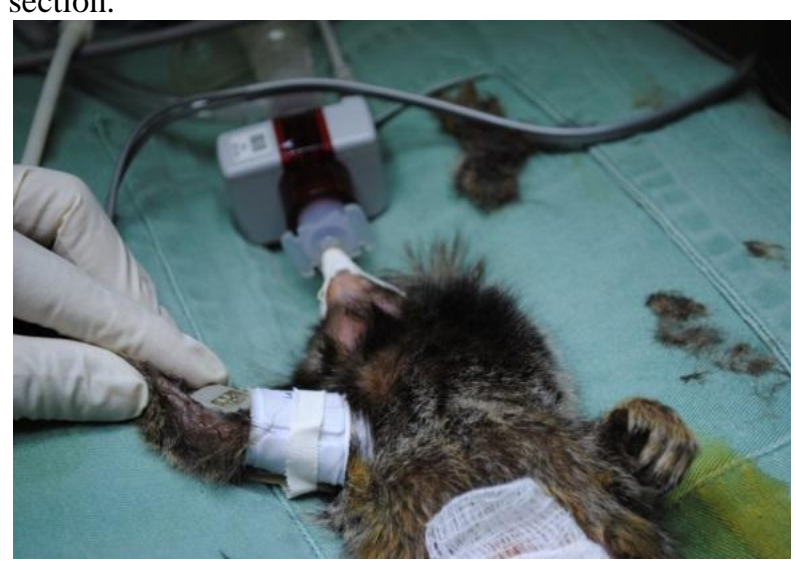

Figure 3. Callithrix jacchus undergoing anesthetic procedure.

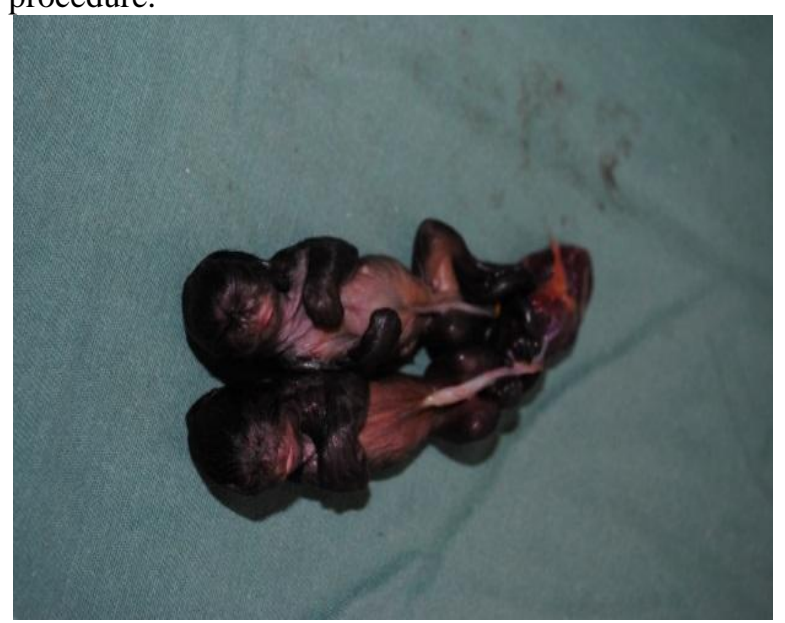

Figure 4. Callithrix jacchus fetuses presenting malformation.

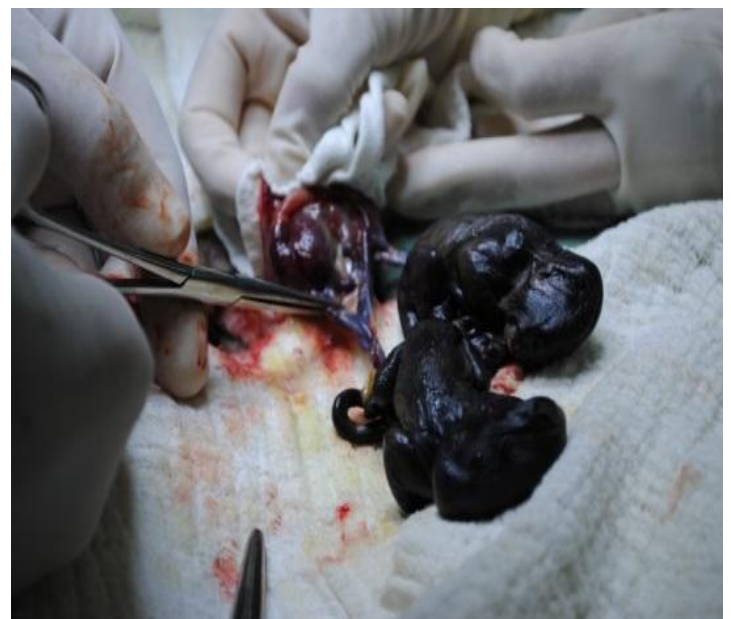

Figure 2. Cesarean surgery in Callithrix jacchus.

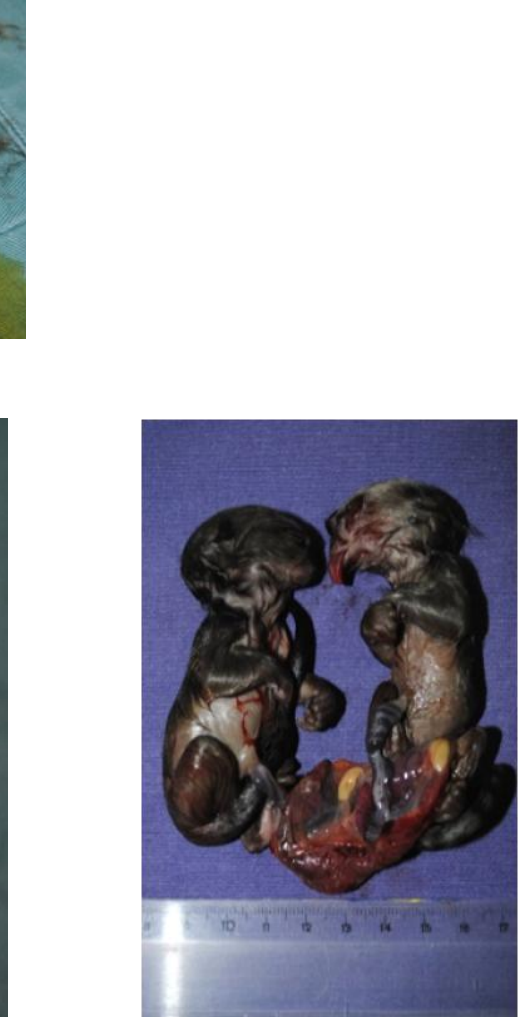

Figure 5. Callithrix jacchus fetuses presenting malformation 
The emotional state of the pregnant is an influential factor, especially if there is any emotional tension during the first trimester of pregnancy. The stress causes a cortisone release, a substance with teratogenic effect (Capelozza Filho, 1988).

During the pregnancy, notes were taken regarding any stressful agents seen, as well as observations regarding the behavior of the animals. The observations suggest that, on days when there were stressful events, the number of alarm vocalizations, arched gait and back leaps increased considerably when compared to days when no stressful events happened (Table 3).

Table 3. Mean number of behaviors related to alert attitudes in the presence and absence of stressful agents in Callithrix jacchus primates

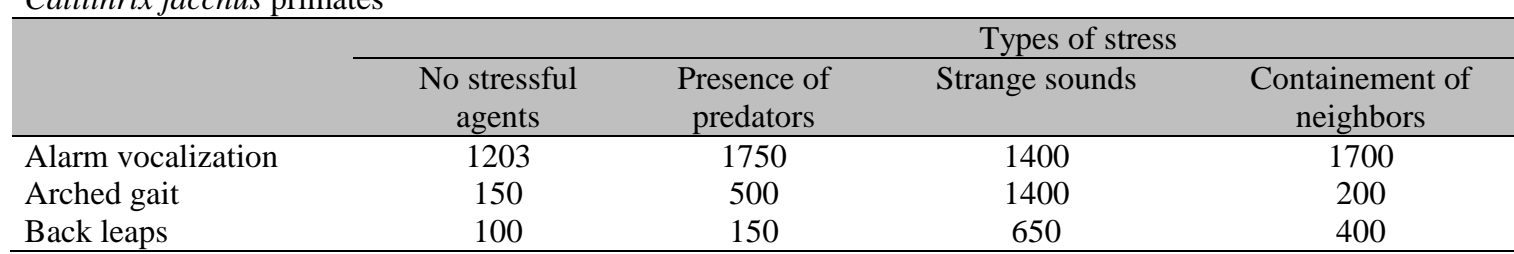

\section{CONCLUSIONS}

Due to the difference in the behavior of the animals in days with no stressful events and due to the reports seen in the literature, it is possible that the high incidence of stillborn presenting malformations may be related to high levels of stress in the group.

\section{ACKNOWLEDGEMENTS}

We thank the Research Support Foundation of the State of São Paulo (Fundação de Amparo à Pesquisa do Estado de São Paulo - FAPESP) for the financial support given to this study (2009/52654-9; 2010/51926-2).

\section{REFERENCES}

BARROS, M.; TOMAZ, C.Non-human primate models for investigating fear and anxiety. Neurosci. Biobehav., v.26, p.187-201, 2002.

CAPELOZZA FILHO, L. Conceitos vigentes na epidemiologia das fissuras lábio-palatinas. Rev. Bras. Cirur. v.77, p.223-230, 1988.

CHARIL, A.; LAPLANTE, D.P.; VAILLANCOURT, C.; KING, S. Prenatal stress and brain development. Brain. Res. Rev. v.65, p.56-79, 2010.

EISENBERG, J.F. Comparative ecology and reproduction of New World monkeys. In: KLEIMAN, D.G. The Biology and conservation of Callitrichidae. Washington, D.C.: Smithsonian Institute Press, 1977. p.39-71.

FRENCH, J.A.; BREWER, K.J.; SCHAFFNER, C.M. et al. Urinary steroid and gonadotropin excretion across the reproductive cycle in female Wied's black tufted-ear marmosets (CallithrixKuhli). Am. J. Primatol. v.40, p.231-245, 1996.
HEARN, J. P. (Ed.) (1983): Reproduction in New World primates: new models in medical science. Lancaster: MTP Press Ltd. In: Rylands, A. B. and Anzenberger, G., Introduction: New World Primates. Int. Zoo Yearbook, 46: 4-10. doi: 10.1111/j.17481090.2012.00182.x, 2012.

JOHNSON, E.O.; KAMILARES, T.C.; GOLD, P.W.; CHROUSOS, G.P. Environmental stress and reproductive sucess in the common marmoset (Callithrix jacchus). Am. J.Primatol. v.25, p.191-201, 1991.

MODOLIN, M.; CERQUEIRA, E.M. Etiopatogenia. In: ALTMANN, E.B.C (Ed). Fissuraslabiopalatinas. Carapicuiba: Pró-Fonodepartamento editorial, 1994. p.25-30.

NG, P.C. Effect of stress on the hypothalamicpituitary-adrenal axis in the fetus and newborn. $J$. Pediatr. v.158, p.3-41, 2011.

PRESTES, N.C.; FERREIRA, J.C.P; FERRAZ, M.C.; GAROFALO, N.A. Cesarean sections in marmosets white tuffed marmoset (Callithrix jacchus). Vet. Zootec. (UNESP), v.1, p.7, 2014.

SECKL, J.R.; HOLMES, M.C. Mechanisms of disease: glucocorticoids, their placental metabolism and fetal 'programming' of adult pathophysiology, Natural Clinical Practice Endocrinol.Metab. v.3, p.479-88, 2007.

STEVENSON, M.F.; RYLANDS, A.B. The marmosets, genus Callithrix. In: MITTERMEIER, R.A.; RYLANDS, A.B.; COIMBRA-FILHO A.F.; FONSECA, G.A.B. Eds. Ecology and Behavior of Neotropical Primates, v.2. Washington D.C: World Wildlife Fund, 1988. p. 131-222. 